\title{
無動力撹拌機構を有する新規低コストメタン発酵リアクターの開発
}

\author{
小林 拓 朗* 宇佐見 心** 李 玉 友 ${ }^{* * *}$
}

\section{Development of an Advanced Low-cost Methane Fermentation Reactor with Self-agitation System}

\author{
Takuro KOBAYASHI ${ }^{*}$, Shin USAMI** and Yu-You LI*** \\ * National Institute for Environmental Studies, Onogawa 16-2, Tsukuba, Ibaraki 305-0053, Japan \\ ** Department of Civil and Environmental Engineering, Tohoku University, 6-6-06 Aza-Aoba, Aramaki, Aoba-ku, Sendai, Miyagi 980-8579, \\ Japan \\ *** Graduate School of Environmental Studies, Tohoku University, 6-6-06 Aza-Aoba, Aramaki, Aoba-ku, Sendai, Miyagi 980-8579, Japan
}

\begin{abstract}
Continuous operation treating $100 \mathrm{~g} \cdot \mathrm{L}^{-1}$ total solids (TS) simulated food waste was investigated using a novel methane fermentation reactor that enables the agitation of the fermentation liquid without electricity. In this study, the overall performance and reaction attributes of the reactor were evaluated. Under mesophilic condition and at different chemical oxygen demand $\left(\mathrm{COD}_{\mathrm{Cr}}\right)$ loading rates $\left(5\right.$ to $\left.10 \mathrm{~kg} \cdot \mathrm{m}^{3} \cdot \mathrm{d}^{-1}\right)$, the reactor achieved 220 days of stable continuous operation. Inside the reactor, the continuous change in the liquid level and the 5 to 16 times self-agitation occurred daily, which was likely responsible for the distribution of organic load near the inlet port of the reactor. The reactor attained $0.72-0.82 \mathrm{~m}^{3} \cdot \mathrm{g}^{-1}$-TS biogas production yield and $79.4-85.5 \% \mathrm{COD}_{\mathrm{Cr}}$ reduction on average, and a small amount of volatile fatty acid (VFA) was detected in the effluent. These results suggest that the novel reactor investigated is comparable in biogas production yield and $\mathrm{COD}_{\mathrm{Cr}}$ reduction and superior in residual VFA level to the completely stirred tank reactor, in the treatment of same simulated food waste used in a previous study.
\end{abstract}

Key words: Low cost, Methane fermentation, Reactor, Self-agitation

\section{1.はじめに}

固形物濃度の高い廃裹物系バイオマスのメタン発酵施 設は，世界的にはアジア地域に集中しており，1,000 万 基を超える家庭用小規模発酵施設が中国とインドに分布 している1)。中国の農村部では約 1 億 4 千万世帯で小規 模発酵施設の導入が見込まれており，2010年までにそ れの 4,000 万基の導入を目標としている ${ }^{2)}$ 。これらの施 設では，簡素な低コスト型発酵槽が利用されている。そ れは一般的には無加温, 無擋拌の押し出し流れ型の方式 であり ${ }^{3)}$, モニタリング等の管理も必要としない簡素な システムである。当然ながらそれは低効率であり, 十分 な処理を達成するには 40 〜 50 日程度の長い HRT を要 し, 大きな容量の装置となる ${ }^{3 \sim 5)}$ 。無摚拌のメタン発酵 は, 投入基質中の固形物の槽内への沈殿蓄積を引き起こ し，それが運転上の問題を生じることが指摘されてい る ${ }^{6)}$ 。また，中国農村部で現在普及しているそうした伝 統的低コスト型発酵槽は, 設備の高度化および維持運営 コスト低減が課題視されていることが徐らにより報告 されている ${ }^{7)}$ 。従って, 先進国で培ってきた技術をべー スとし, 従来の低コスト型メタン発酵槽を高度化するこ
とでそうした問題に対して貢献できると考えられる。し かし，これまでに低コスト型メタン発酵槽の高度化に焦 点を当てた研究がほとんどない。著者らは, 電力を要さ ず，仕切り板とU 字管とを利用した簡単な原理によっ て，従来の低コスト型発酵槽には不備であった擋拌機能 を付与した新規な低コスト型メタン発酵リアクターの開 発に取り組んだ。

メタン発酵において擋拌は次の 2 つの効果を持つと考 えられる：(1)微生物と有機物との接触効率を高め, 処理 効率を向上させる, (2)リアクター内の混合液を均一に保 ち, スカム形成 - 固形物沈殿による槽容積減少や, 短絡 流生成を回避する。とくに, $100 \mathrm{~g} \cdot \mathrm{L}^{-1}$ 以上の高 TS 濃度 の基質の処理において，上に述べた撹拌の効果が大きい ことが報告されている ${ }^{6)}$ 。小規模施設で処理が想定され るのは比較的 TS 濃度の高い固形性バイオマスであるた め, その効果が期待できる。例えば, 無搅找装置で実際 に問題となっているスカム形成や固形物の沈殿蓄積の回 避である。また, 易分解性の高有機物濃度の基質を擋拌 がない押出流れ方式で処理する場合, 流入口付近に負荷 が集中して, 有機酸蓄積を生じる危険性が高い。槽内で 擋拌が行われていれば，負荷は分散し，そうした危険を

* 国立環境研究所循環型社会・廃棄物研究センター ₹305-0053 つくば市小野川 16-2

** 東北大学大学院工学研究科土木工学専攻 ₹980-8579 仙台市青葉区荒巻字青葉 6-6-06

*** 東北大学大学院環境科学研究科 T980-8579 仙台市青葉区荒巻字青葉 6-6-06 
回避できる。以上のような理由から，固形性バイオマス を処理する低コスト型メタン発酵システムにおいて，擋 拌が可能となることの意義は大きい。

著者らが開発したリアクターは，4つのチャンバーか らなる反転流構造であり, 流入口付近のチャンバーでバ イオガスを貯留し，それが一定量に達したときに，貯留 されたガスがU字管を通して隣のチャンバーへ一気に 移動する仕組みとなっている。このガス移動によって発 酵液は流入口方向に向かって引き戻され，このとき生じ る液流動によって擋拌を行う。このようにして, 発酵液 の擋拌をリアクター形状の工夫によって無動力で行うの が新規無動力擋拌リアクターの特徵である。本研究では, 開発した無動力擋拌リアクターの性能および特性を把握 することを目的として，ラボスケールの実験装置を利用 し, 生ごみのメタン発酵連続運転による性能評価と反応 機構の考察を行った。

\section{2. 実験方法}

\section{1 連続運転装置}

本研究のメタン発酵連続運転装置の概要図を Fig. 1 に 示す。基質には水道水で TS $100 \mathrm{~g} \cdot \mathrm{L}^{-1}$ に希釈した模擬生 ごみ をミキサーによって微細化したものを使用した。 その平均的性状は Table 1 に示す。基質は容量 $15 \mathrm{~L}$ の機 械擋拌式タンクにおいて $4^{\circ} \mathrm{C}$ で保持し, タイマー制御式 のポンプによって 2 時間に 1 回ごとメタン発酵リアク ターに間欠投入した。メタン発酵リアクターは有効容量 $43 \mathrm{~L}$ で, 内部は 4 つのチャンバー (Fig. 1 の左から第 1 , 第 2, 第 3, 第 4）に分けられている。リアクターの高 さは $80 \mathrm{~cm}$, 横幅 $80 \mathrm{~cm}$, 奥行きは $10 \mathrm{~cm}$ である。各チャ

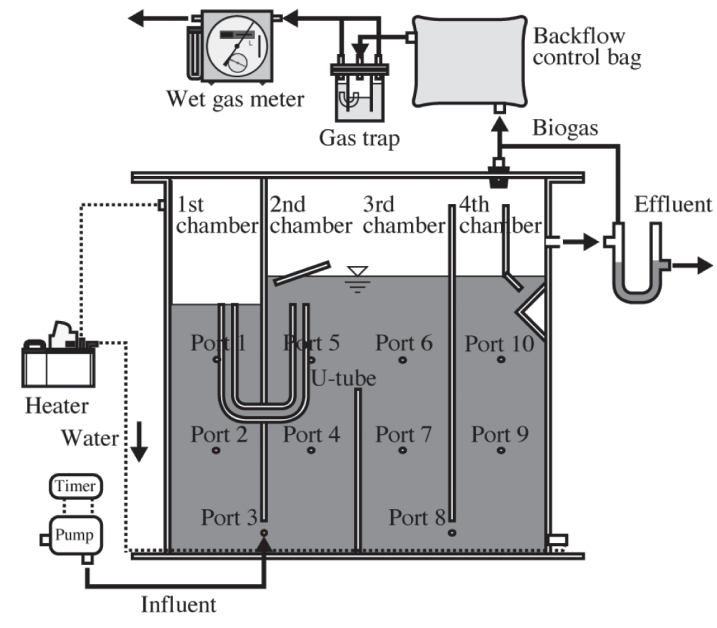

Fig. 1 Schematics of the system for continuous experiment.
ンバーの横幅は等しく $20 \mathrm{~cm}$ となっている。各チャン バーには污泥サンプリング用のポートが，Fig. 1 に示す ように合計 10 箇所取り付けられている。リアクターの 温度は, ウォータージャケットに温水を循環することで $35^{\circ} \mathrm{C}$ に制御した。基質投入は Fig. 1 に示すポート 3 か ら行った。污泥流出は, リアクター内に有効容量以上の 污泥が蓄積されたとき Fig. 1 に示す第 4 チャンバー上部 の U 字管から自然流下によって行われる。第 1 チャン バーの気相部のみが密封されており, 第 $2 \sim 4$ チャンバー のそれらは吹き通しの構造で, バイオガスは第 4 チャン バー天井部のポートからリアクター外に排出される。種 污泥は, 宮城県仙塩浄化センターに設置された下水污泥 の中温嫌気性消化槽から採取した消化污泥を使用した。 HRT は 75 日，50日，30日，20日，15日と段階的に短 縮して運転を行った。また，第 2 チャンバーの流入口方 向の壁面付近から, 生物脱硫用の空気をローラーポンプ によって連続的に投入した。空気吹き込み速度は, 平 均バイオガス生成速度の $2.5 \%$ になるように設定し, 各 HRT でその速度は固定した。

撹拌の動作原理はFig. 2 に示すようになっている。擋 拌が行われた直後の状態は Fig. 2 の a に示すようになっ ている。気相部が密封された第 1 チャンバーでは, 発生 するバイオガスによって污泥の液面が徐々に押し下げら れていく (Fig. 2 b)。それに伴って, 第 2 。第 4 チャン バーに扔ける液面は上昇する。第 2 第 4 チャンバーの 気相部は生物脱硫の反応スペースとなっている。液面上 昇に伴い, この脱硫スペースに対し発酵污泥が栄養とし て供給される。押し下げられた液面がU 字管の底部ま で達したとき，第 1 チャンバー気相部に貯留されたバイ オガスはU 字管を通して隣のチャンバーへ一気に移動 する $($ Fig. 2 c) 。発酵液は第 1 チャンバーへ向かって引 き戻され, 第 1 チャンバー液面は上昇し, 第 $2 \sim 4$ チャ ンバー液面は下降する。このときに生じる液流動によっ て槽内の擋拌が行われる（Fig. 2 d）。

\section{2 分析方法}

バイオガス生成量は湿式ガスメータ（Shinagawa, W-NK）を用いて測定し，ノルマル状態の量に換算 した。ガス組成の分析には TCD ガスクロマトグラフ （Shimadzu, GC-8A）を使用した。カラムにはPorapak Q （Shimadzu GLC）を充填したステンレスカラムを使用し, カラムおよび検出器の温度はそれぞれ $100^{\circ} \mathrm{C}, 70^{\circ} \mathrm{C}$ とし た。運転 136 日目からは, カラムを酸素が測定可能な SHINCARBON ST（Shimadzu GLC）に変更した。カラ ムおよび検出器の温度はそれぞれ $200^{\circ} \mathrm{C}, 70^{\circ} \mathrm{C}$ とた。 アルカリ度, $\mathrm{NH}_{4}{ }^{+}-\mathrm{N}, \mathrm{T}-\mathrm{KN}, \quad \mathrm{S}-\mathrm{COD}_{\mathrm{Cr}}$, Volatile fatty acid

Table 1 Average characteristics of stimulated food waste taken from the feed tank during operation.

\begin{tabular}{|c|c|c|c|}
\hline $\begin{array}{c}\text { HRT (d) } \\
\text { pH }\end{array}$ & $\begin{array}{c}30 \\
4.30 \pm 0.14\end{array}$ & $\begin{array}{c}20 \\
4.47 \pm 0.10\end{array}$ & $\begin{array}{c}15 \\
4.28 \pm 0.39\end{array}$ \\
\hline $\mathrm{TS}\left(\mathrm{g} \cdot \mathrm{L}^{-1}\right)$ & $94.5 \pm 0.9$ & $99.2 \pm 3.6$ & $98.9 \pm 3.5$ \\
\hline $\operatorname{VS}\left(g \cdot L^{-1}\right)$ & $89.0 \pm 0.7$ & $93.2 \pm 3.8$ & $92.5 \pm 3.3$ \\
\hline $\mathrm{T}-\mathrm{COD}_{\mathrm{Cr}}\left(\mathrm{g} \cdot \mathrm{L}^{-1}\right)$ & $145.0 \pm 4.6$ & $143.0 \pm 4.4$ & $146.1 \pm 5.8$ \\
\hline $\mathrm{S}-\mathrm{COD}_{\mathrm{Cr}}\left(\mathrm{g} \cdot \mathrm{L}^{-1}\right)$ & $58.2 \pm 2.8$ & $60.0 \pm 1.6$ & $63.9 \pm 5.6$ \\
\hline $\mathrm{VFA}\left(\mathrm{mg} \cdot \mathrm{L}^{-1}\right.$ as acetate $)$ & $1,730 \pm 816$ & $993 \pm 198$ & $1,300 \pm 706$ \\
\hline
\end{tabular}




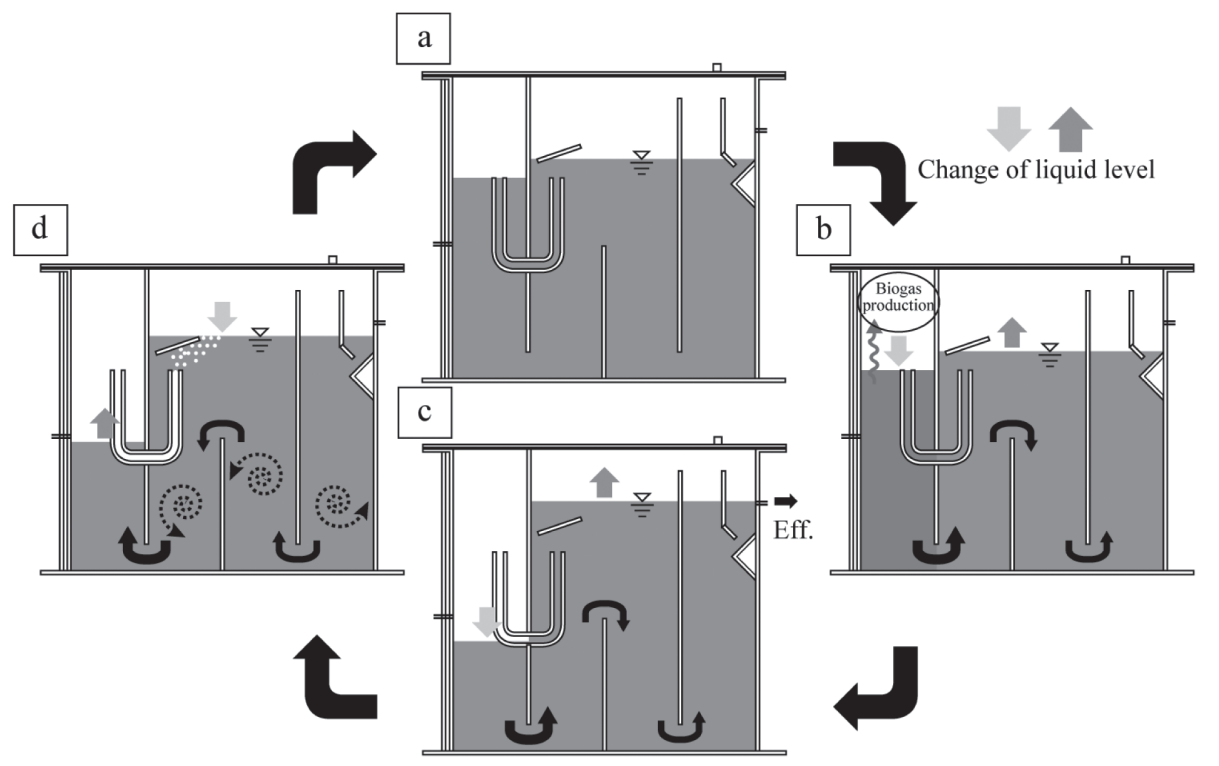

Fig. 2 Principle of operation of the self-agitated reactor.

（VFA）の測定に使用する上清は，3,000 rpm，20 分の遠 心分離と $0.45 \mu \mathrm{m}$ 孔径のフィルターろ過を経て準備し た。アルカリ度, TS, VS, SS, VSS の測定は下水試験 方法 ${ }^{9)}$ に従って行った。 $\mathrm{COD}_{\mathrm{Cr}}$ の測定はAPHA Standard Method $^{10)}$ に従った。アンモニア性窒素はインドフェノー ル青吸光光度法により, 下水試験方法 ${ }^{9)} に$ 準じて測定し た。ケルダール窒素は HACH 社のダイジェスタール分 解器（Models 23120-20）を用いて有機性窒素をアンモ ニア性窒素に分解した後, 上記のインドフェノール青 吸光光度法でアンモニア性窒素として測定した。 $\mathrm{pH}$ 測

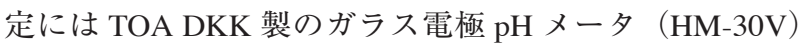
を使用した。VFAの測定には, FID ガスクロマトグラ フ（Agilent 6890）を使用した。カラムは $30 \mathrm{~m}$ のキャ ピラリーカラム (Agilent, DB-WAXetr) を用いた。カ ラムは $125^{\circ} \mathrm{C}$ で 5 分, $125^{\circ} \mathrm{C}$ から $180^{\circ} \mathrm{C}$ まで $15^{\circ} \mathrm{C} /$ 分, $180^{\circ} \mathrm{C}$ で 12 分の段階的昇温操作を行った。検出器の温 度は $280^{\circ} \mathrm{C}$ とした。

\section{3. 結果および考察}

\section{1 連続運転データの推移}

スタートアップ後, 段階的に HRT を短縮しながら, それぞれ HRT 30 日では 74 日, HRT 20 日では50日, HRT 15 日では 45 日間の運転を行った。その期間, 平均 $\mathrm{COD}_{\mathrm{Cr}}$ 容積負荷はそれぞれ $4.82 \mathrm{~kg} \cdot \mathrm{m}^{-3} \cdot \mathrm{d}^{-1}$ (HRT 30 日), $7.16 \mathrm{~kg} \cdot \mathrm{m}^{-3} \cdot \mathrm{d}^{-1}$ (HRT 20 日), $9.74 \mathrm{~kg} \cdot \mathrm{m}^{-3} \cdot \mathrm{d}^{-1}$ (HRT 15 日） であった。Fig. 3 において, A にバイオガス生成速度と メタン濃度の推移を示す。各 HRT においてバイオガス 生成速度とバイオガス組成は, 常に標準偏差が平均值 の $10 \%$ 以内で安定が持続されたので, HRT 切り替え後, HRT と同じ日数経過以降の運転期間を定常状態と定義 して，平均的な運転性能を検討することにした。定常 状態期間におけるバイオガス生成速度は, リアクター 容積あたり平均 $2.23 \pm 0.10 \mathrm{~L} \cdot \mathrm{L}^{-1} \cdot \mathrm{d}^{-1}$ （HRT 30 日）, 平 均 $3.46 \pm 0.13 \mathrm{~L} \cdot \mathrm{L}^{-1} \cdot \mathrm{d}^{-1}$ (HRT 20 日 ), 平均 $4.57 \pm 0.33 \mathrm{~L}$ $\cdot \mathrm{L}^{-1} \cdot \mathrm{d}^{-1}$ (HRT 15 日) となり, HRT 短縮に伴い増大し ながら, 各 HRT で安定して推移した。脱硫のための空
気を吹き込んでいる期間において，各 HRTにおける平 均メタン濃度は $55.7 \sim 57.6 \%$, 平均二酸化炭素濃度は $41.1 \sim 43.1 \%$ 範囲であった。本研究では, 生物脱硫 を行うためバイオガス生成速度の $2.5 \%$ 割合で空気を 吹き込んでいる。本研究と同様にそれの $5 \%$ の割合で空 気を吹き込んだ研究では, メタン発酵性能に対して影響 は認められなかったが, バイオガス中のメタン濃度が平 均約 $3 \%$ 減少し, 約 $1 \%$ の酸素が残留した ${ }^{11)}$ 。本研究で は, HRT 30 日で運転中の 57 日目から 64 日目までは一 時的に空気吹き込みを停止しているが, HRT 30 日にお ける空気吹き込みありの時期はそれなしの時期と比較し てバイオガス中のメタン濃度が平均約 $1 \%$ 低かった。一 方, 実験期間を通して酸素濃度は $0.09 \%$ の検出限界以 下であった。酸素はすべて脱硫等のために使用された と考えられる。Fig. 3 B には流入および流出液の $\mathrm{COD}_{\mathrm{Cr}}$ 濃度とプロセスでの COD $_{\mathrm{Cr}}$ 減量化率, Fig. 3 C には流出 液の VFA 濃度, Fig. 3 D には流出液の pH とアルカリ度 それぞれの推移を示している。 $\mathrm{COD}_{\mathrm{Cr}}$ 減量化率は HRT 30 日，20日，15日の定常状態において，それぞれ平均 $85.5 \pm 0.6 \%, 80.7 \pm 0.9 \%, 79.4 \pm 2.3 \%$ で安定して推移し た。流出液の VFA 濃度はすべての HRT 条件の定常状態 期間, 常に $100 \mathrm{mg} \cdot \mathrm{L}^{-1}$ as acetate 以下でほとんど検出さ れなかった。流出液 $\mathrm{pH}$ は, 運転期間を通じて平均約 7.8 〜 8.0 の範囲であり, メタン発酵に適した水準であった。 流出液アルカリ度（pH 4.8）は，運転期間中 7 $10 \mathrm{~g}$ $\cdot \mathrm{L}^{-1}$ as $\mathrm{CaCO}_{3}$ の範囲で分布した。図示はしていないが, 流出液の $\mathrm{NH}_{4}{ }^{+}-\mathrm{N}$ 濃度は運転期間中 $1,500 \sim 2,000 \mathrm{mg} \cdot \mathrm{L}^{-1}$ の範囲であり，一般的に中温メタン発酵で阻害が生じる と考えられる水準 $\left(3,000 \mathrm{mg} \cdot \mathrm{L}^{-1}\right)^{12)}$ より低かった。以上 述べてきたバイオガス生成速度および組成, 主な指標 $\left(\mathrm{COD}_{\mathrm{Cr}}\right.$ 減量化率, $\mathrm{pH}$, アルカリ度) は, 各 HRT におい て標準偏差が平均值の $10 \%$ 以内で安定しており, VFA はほとんど未検出かつ $\mathrm{pH}$ は適正範囲であった。このこ とから, 本リアクターは, $\mathrm{COD}_{\mathrm{Cr}}$ 容積負荷 $4.82 \sim 9.74$ $\mathrm{kg} \cdot \mathrm{m}^{-3} \cdot \mathrm{d}^{-1}$ の条件に抏いて, 安定かつ安全な水準の連続 運転が可能であったと判断できる。 
A

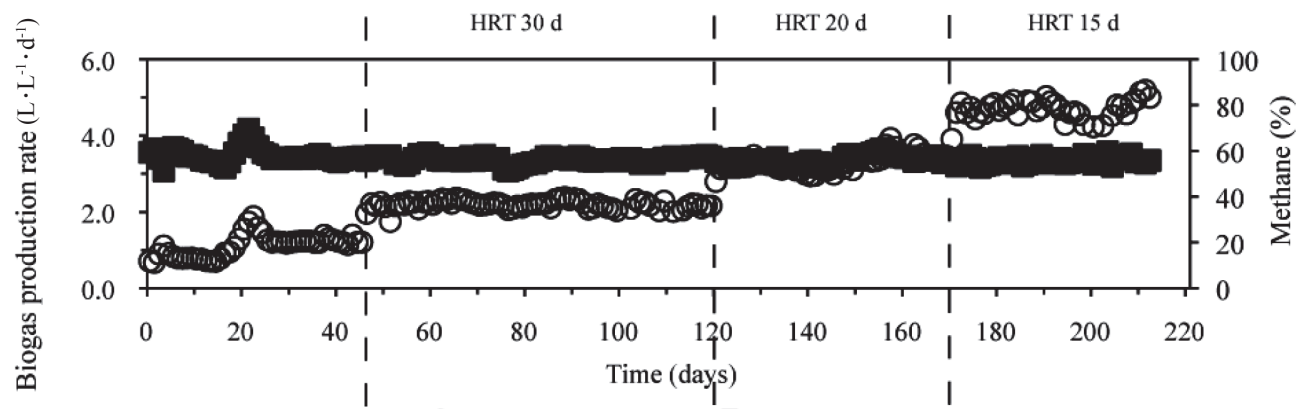

B

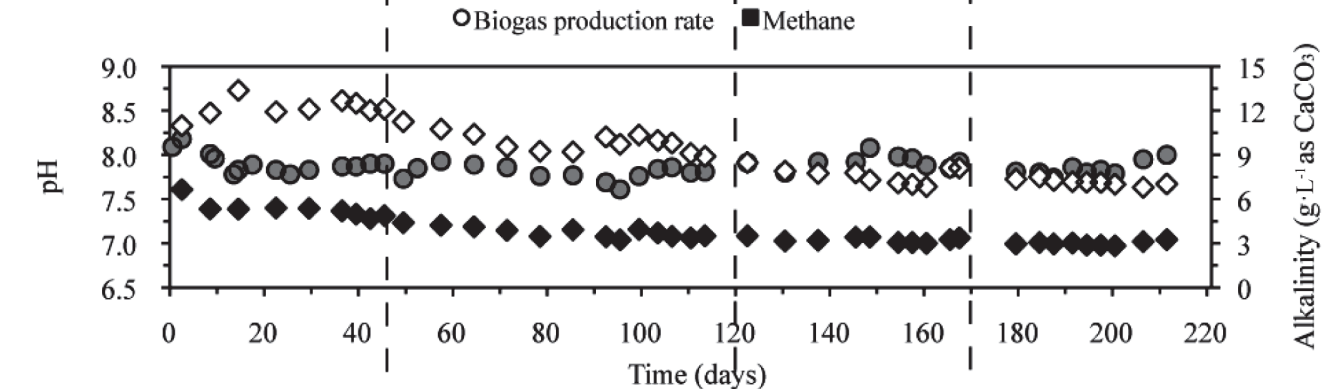

C

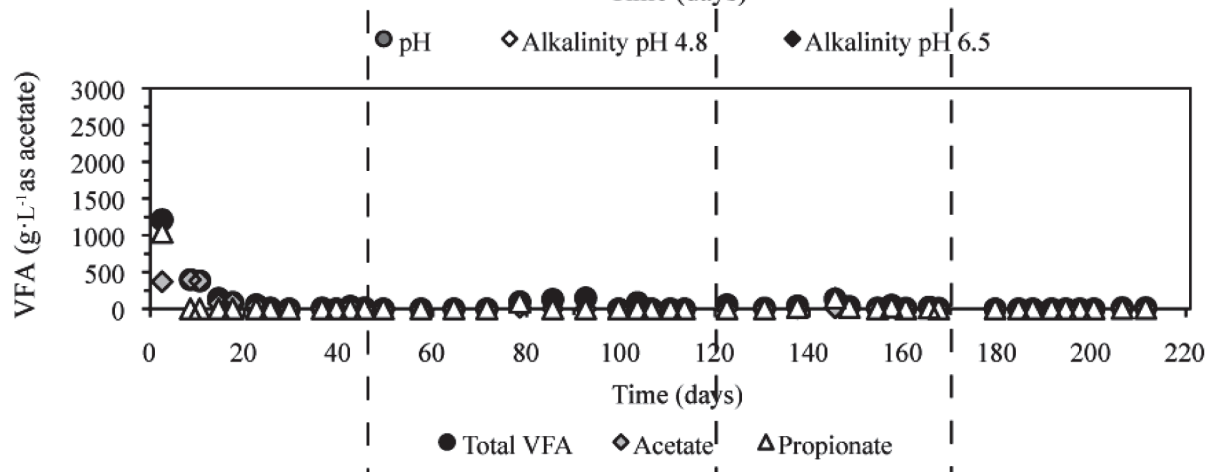

D

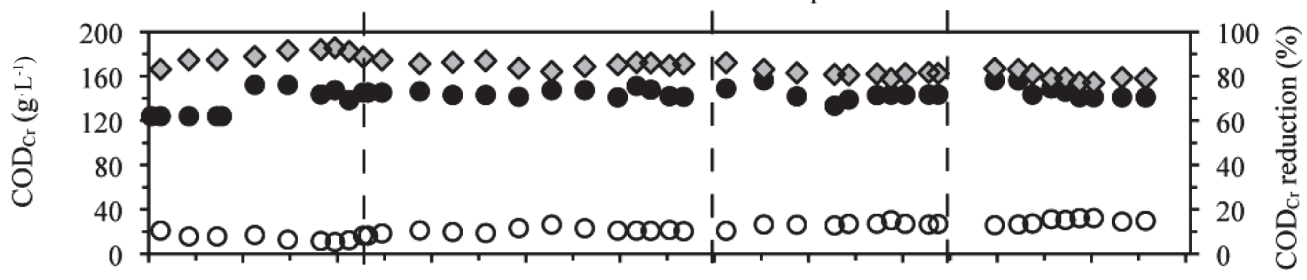

$\mathbf{E}$

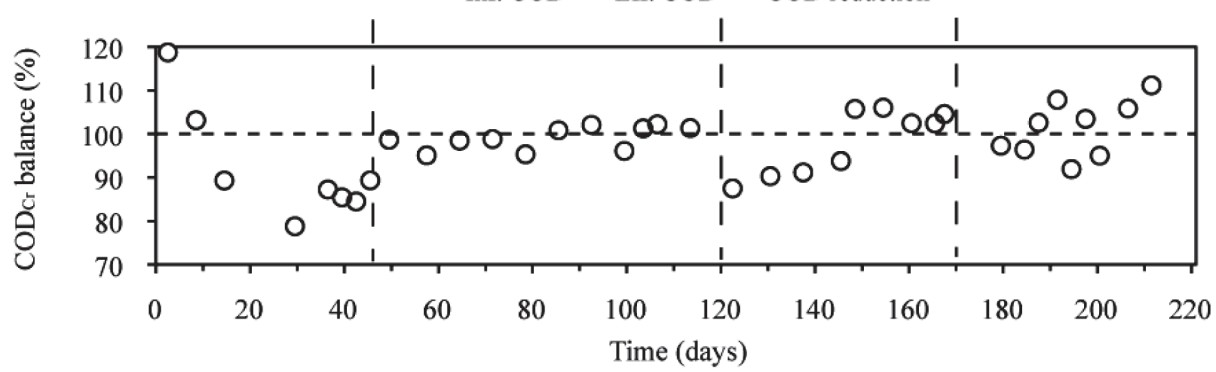

Fig. 3 Evolutions of reactor performance during continuous operation.

\section{2 物質収支}

投入された生ごみの物質収支を把握するために，投入 基質と流出液，バイオガスとの間の COD 収支を計算し た。Fig. 3 E は, 各分析日における（流出液の $\mathrm{COD}_{\mathrm{Cr}}+$ 生成メタンの $\mathrm{COD}_{\mathrm{Cr}}$ 当量) / (流入基質の $\mathrm{COD}_{\mathrm{Cr}}$ ) によっ て計算される COD 収支を示している。HRT 30 日, 20 日， 15 日の各定常状態期間における COD 収支の平均值は, それぞれ $100 \pm 3 \%, 102 \pm 6 \%, 100 \pm 5 \%$ であった。こ の結果は, リアクターに投入された基質の COD 成分は
浮遊スカム形成や沈殿蓄積によるロスがほとんどなく, メタンガスと流出液とでほとんど回収できていたことを 意味する。実際, スカム形成は運転中に目視では確認で きなかった。また，Karim ら ${ }^{6)}$ はリアクター内における 固形物蓄積は, TS と VS の物質収支によって判断でき ると指摘している。よく擋挥が行われているリアクター は TS 減量化率と VS 減量化率とが近い数值となるが, 無擋拌のリアクターでは TS 減量化率がVS 減量化率と 比較して顕著に高い数値を示すとしている。この現象は, 
次のことを意味している。VS 成分はガス化されたもの 以外は流出液中から回収されるが, TS 成分はガス化さ れたもの以外に沈殿した灰分の一部が槽内に蓄積し, 流 出液中から回収されない場合がある。つまり, 固形物沈 殿蓄積が生じているリアクターでは, TS 減量化率はVS のそれと比較して, 被分解分に沈殿分が上乗せされて大 きくなる。この観点から, 本リアクターの運転結果を評 価すると以下のようになる。本研究と同組成の模擬生ご みを使用して中温の完全混合リアクター（CSTR）で運 転を行った李らの研究 ${ }^{8)}$ では, 平均 TS 減量化率と平均 VS 減量化率との比率が約 0.94 (HRT 30 日), 約 0.94 (HRT 15 日）であったのに対し, 本研究のそれは 0.94 (HRT 30 日), 0.95 (HRT 20 日), 0.94 (HRT 15 日）であった。 これらの結果は, TS と VS の物質収支の観点から判断 して, 本リアクターは固形物沈殿蓄積を CSTR と同程度 回避できていることを示している。

\section{3 リアクターの内部の反応状況}

運転期間中に各チャンバーにおける污泥性状の推移 を追跡した。污泥採取を行ったポートは，Fig. 1 に示 す port 2，4，7，9 である。污泥は撹汼が起きた直後に 採取した。HRT30日の定常状態の期間において，すべ てのチャンバーから VFA はほとんど検出されなかっ た。各チャンバーで $\mathrm{pH}$ は 7.5〜 7.9, アルカリ度は 10.0 $\sim 11.9 \mathrm{~g} \cdot \mathrm{L}^{-1}$ as $\mathrm{CaCO}_{3}$ の範囲で分布しており, それぞ れ各チャンバー間での標準偏差が常に平均值の $10 \%$ 以 内であり，チャンバーごとのばらつきは小さかった。 HRT 20 日の期間においては, 定常状態期間である 161 日目と 167 日目にはすべてのチャンバーで約 $500 \mathrm{mg}$ $\cdot \mathrm{L}^{-1}$ acetate 以下の低い水準となった。各チャンバーに おける VFA 濃度は, 第 1 , 第 $2>$ 第 $3>$ 第 4 の順に減少 し，第 4 チャンバーでは $10 \mathrm{mg} \cdot \mathrm{L}^{-1}$ as acetate 以下であっ た。161，167日目における $\mathrm{pH}$ とアルカリ度は各チャン バー間での標準偏差が平均值の $10 \%$ 以内であった。 $\mathrm{pH}$ は $7.6 \sim 7.9$, アルカリ度は $6.2 \sim 8.2 \mathrm{~g} \cdot \mathrm{L}^{-1}$ as $\mathrm{CaCO}_{3}$ の 範囲で分布していた。HRT 15 日の期間, 184, 206, 211 日目において VFA は第1 第3 チャンバーで $350 〜 1,150$ $\mathrm{mg} \cdot \mathrm{L}^{-1}$ as acetate の低水準の蓄積が認められたが，第 4 チャンバーでは $80 \mathrm{mg} \cdot \mathrm{L}^{-1}$ as acetate 以下であった。 $\mathrm{pH}$ は, 第 1 〜第 3 チャンバーでは $7.4 〜 7.6$ の範囲, 第 4 チャンバーでは7.7〜 7.9の範囲であった。アルカリ度は, 第 1 第 3 チャンバーでは $4.8 \sim 6.2 \mathrm{~g} \cdot \mathrm{L}^{-1}$ as $\mathrm{CaCO}_{3}$ の範 囲，第 4 チャンバーでは $6.9 \sim 7.3 \mathrm{~g} \cdot \mathrm{L}^{-1}$ as $\mathrm{CaCO}_{3}$ の範囲 であった。こうしたように, 定常状態の期間はリアクター 内部すべてのチャンバーでメタン発酵にとって安全な水 準下での運転が行われていたといえる。

Fig. 4 には，それぞれの HRT の定常状態期間の 1 日 を選んで，擋拌直後すべてのサンプリングポートから採 取した污泥の性状プロファイルを示している。 $\mathrm{pH}$, ア ルカリ度, VFAの分布を見ると, 第 1 〜第 3 チャンバー に相当するポート 1 ～ 7 までと第 4 チャンバーに相当す るポート 8 以降とで異なる傾向を示していることがわか る。つまり，ポート $1 \sim 7$ の領域ではVFA が比較的高 水準であり, ポート 8 以降の領域ではVFA が分解され るとともに $\mathrm{pH}$ とアルカリ度がポート 1 〜 7 の領域と比 較して高水準となっていた。第 1 チャンバーにおける ガス生成速度のリアクター全体におけるそれに占める
割合はそれぞれ平均で，約 23\%（HRT 30 日），約 34\% (HRT 20 日), 約 $34 \%$ (HRT 15 日) であり，バイオガ ス中のメタン濃度は 48 ～58\%の範囲であった。このこ とは, リアクター内における有機物分解反応のほとんど が前半部において起きていることを示している。Fig. 4 の $\mathrm{COD}_{\mathrm{Cr}}$ のプロファイルからは, ポート 8〜10にかけ て約 $8 \mathrm{~g} \cdot \mathrm{L}^{-1}$ の $\mathrm{COD}_{\mathrm{Cr}}$ 濃度減少が認められるが，そのほ とんどがVFA を含む Soluble COD の分解である。Total $\mathrm{COD}_{\mathrm{Cr}}$ から Soluble $\mathrm{COD}_{\mathrm{Cr}}$ を差し引いた固形性 $\mathrm{COD}_{\mathrm{Cr}}$ は, ポート間の標準偏差が平均值の $5 \%$ 以内でほとんど 変化していない。以上のことから判断して, リアクター 前半部は有機物の微細化・酸生成のほとんどとメタン 生成の多くの部分の反応を担当していると考えられる。

Fig. 4 のVFA プロファイルから,リアクター前半部で 蓄積したVFAの分解が後半部のポート 8 〜 10 の領域 でよく進行していることがわかる。ポート 1 〜 7 で検 出されるVFA の内訳は, いずれの時もプロピオン酸が 全VFA の 8 割以上を占めていた。プロピオン酸分解は 水素分圧の影響を強く受けることがよく知られている。 HRT 15 日の期間において, 最もプロピオン酸濃度が高 い第 1 チャンバーの気相部から採取したバイオガスの平 均水素濃度は $0.05 \%$ であったのに対し, VFA がほとん ど検出されない第 4 チャンバーの気相部から採取したバ イオガスからは水素は検出されなかった。このことから, リアクター前半部のポート $1 \sim 7$ の領域と比較して, 後 半部のポート $8 \sim 10$ の領域では水素分圧が低く, VFA の分解が進行しやすい環境が形成されていると考えられ る。以上見てきたように, リアクター内部の反応は, 有 機物の微細化・酸生成のほとんどとメタン生成の多くの 部分の反応を担当する前半部と, 残留した溶解性有機物 やVFA の分解を担当する後半部に役割分担がなされて いる。このようなリアクターの反応特性により, 高い容 積負荷においても流出液中への VFA の残留が回避でき たと考える。

上の結果からポート1〜 7 の領域内においては, $\mathrm{pH}$, アルカリ度, VFA は均一的に分布していた。VSS およ び Total および Soluble $\mathrm{COD}_{\mathrm{Cr}}$ の分布から見ても，ポー ト 1 ～ 7 で顕著なばらつきは認められない。通常，押し 出し流れ方式のメタン発酵リアクターでは, 基質の流入 口から流出口にかけて段階的に基質の分解が進行して いく傾向がある ${ }^{13,14)}$ 。つまり，COD やVFA などは流入 口から流出口にかけて減少していく傾向がよく観察され る。とくに, 流入口付近は高い有機物負荷となり, VFA 蓄積が生じやすい。そうした問題を回避するためにアル カリ度供給を行うケースがある ${ }^{13,15)}$ 。一方, 無動力擋拌 リアクターでは, 基質の平均 $\mathrm{COD}_{\mathrm{Cr}}$ 濃度が $143 \sim 146 \mathrm{~g}$ · $\mathrm{L}^{-1}$ であるにも関わらず, 流入口であるポート 3 を含む ポート 1 〜 の領域で $\mathrm{COD}_{\mathrm{Cr}}$ 濃度は $40 \mathrm{~g} \cdot \mathrm{L}^{-1}$ 付近の濃 度で均一的に分布していた（HRT 15 日）。流入口付近で のVFAの高水準の蓄積も見られなかった。この結果は, ポート $1 \sim 7$ の領域において, 加水分解から酸生成にか けての基質分解の進行段階がほぼ同水準であることを示 していると解釈できる。こうした現象は, (1)無動力擋拌 と(2)リアクター内における污泥の配置変化の 2 要素に起 因していると考える。(1)は擋找によってリアクター内の 污泥の混合を促進する。(2)が意味するのは，擋拌に至る 
A

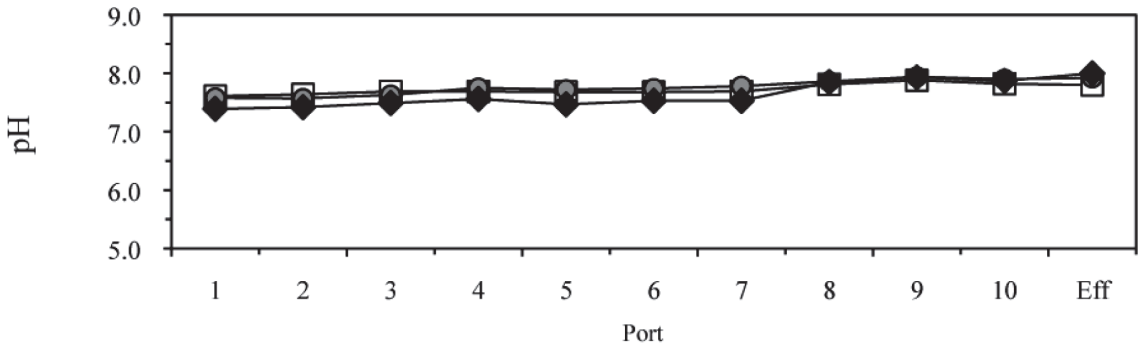

B

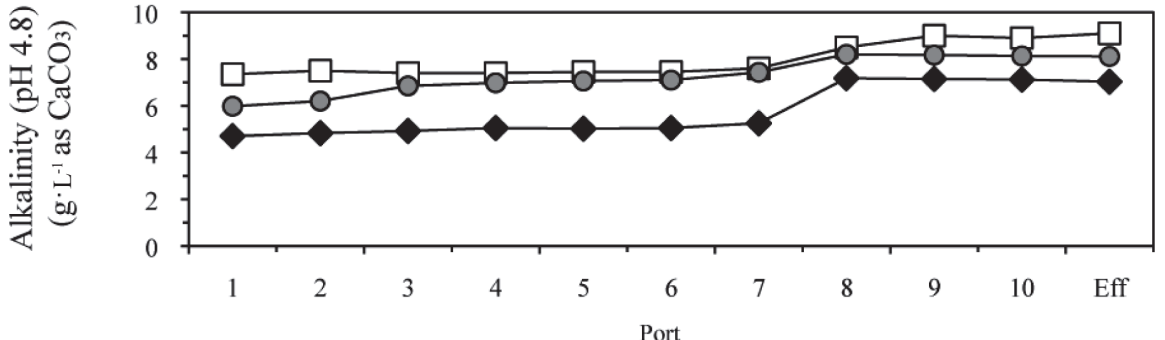

C

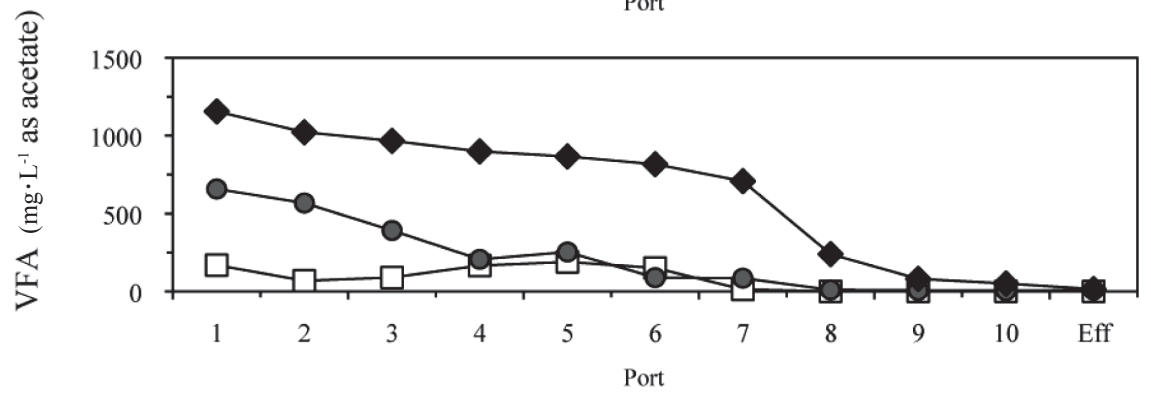

D

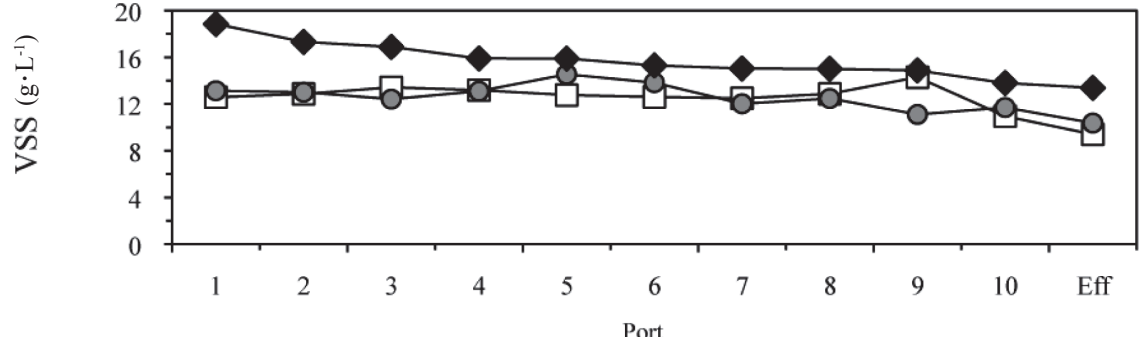

$\mathbf{E}$

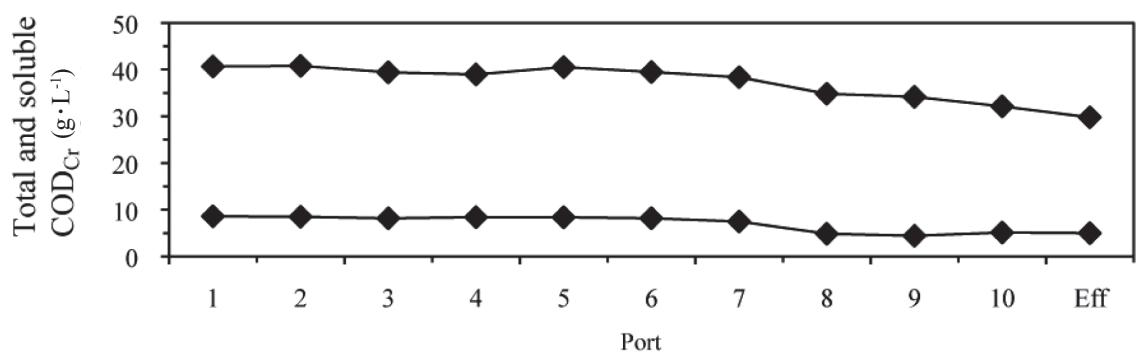

$\longrightarrow$-HRT $30 \mathrm{~d} \quad \longrightarrow$-HRT $20 \mathrm{~d} \quad \longrightarrow$ HRT $15 \mathrm{~d}$

Fig. 4 Profiles in the reactor with different HRTs at steady state.

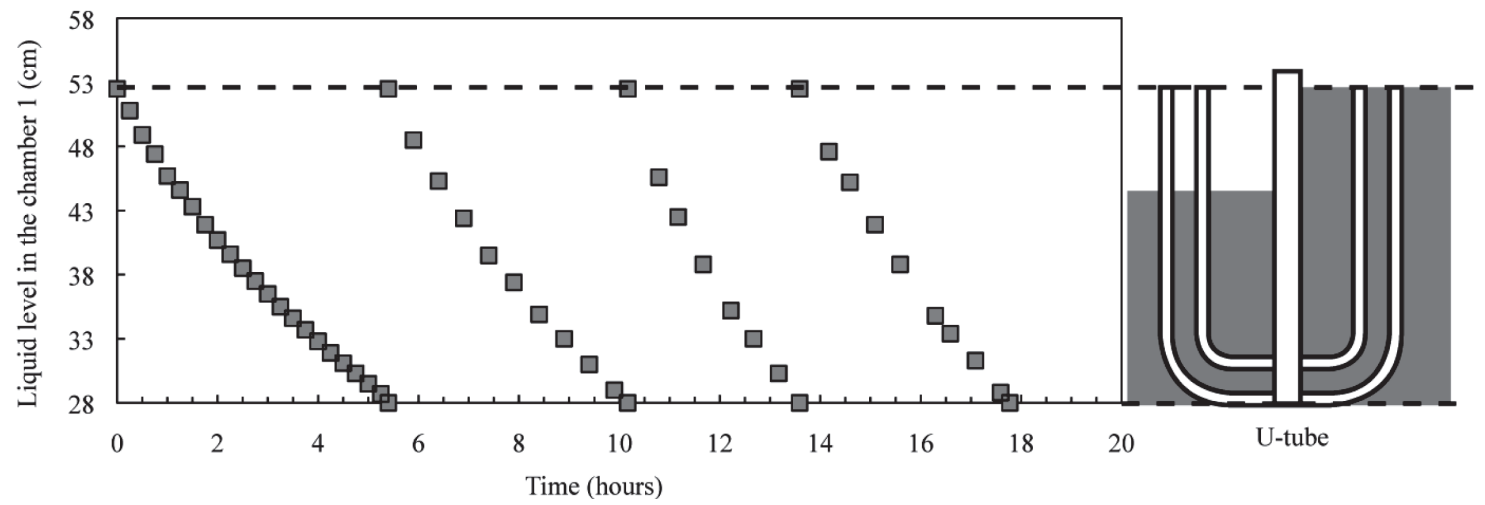

Fig. 5 An example of the change of the liquid level in the chamber 1 at HRT 30 days. 
まで第 1 チャンバー内の污泥が流出方向に向かって次 第に押し出されて行き，また引き戻されるというサイク ルによる污泥の移動である。Fig. 5 はHRT 30 日の運転 期間において，第 1 チャンバー液面の連続的な変化の様 子を記録したデー夕である。縦軸は, 第 1 チャンバー液 面のリアクター底部からの高さを示している。液面が U 字管の底辺に相当する $28 \mathrm{~cm}$ に達したときにガス移動が 生じて擋挥が行われる。Fig. 5 から明らかなように, リ アクター内の污泥の配置は一定のサイクルを持って常 に変化を続けている。基質流入はポート 3 から行われる が, 污泥の配置は絶えず変化しているため, 流入基質と 直接接触する污泥はいつも異なっている。このことが污 泥に対する有機物負荷の分散に寄与していると考えられ る。このような特徵は本無動力リアクター特有のもので あり，許容できる有機物負荷の増大に役立ち得る。

\section{4 無動力擋找の頻度}

擋拌直後から次の撹拌が起きるまでの時間を測定し, 1 日あたりの擋拌回数として擋拌頻度を算出した。各 HRT の定常状態期間において各 7 回以上の測定を行っ て，それぞれ平均擋汼頻度とした。平均擋拌頻度はそ れぞれ, $5.4 \pm 0.8$ 回・ $\mathrm{d}^{-1}$ (HRT 30 日 ), $11.3 \pm 0.4$ 回・ $\mathrm{d}^{-1}$ (HRT 20 日), $16.9 \pm 3.2$ 回· $\mathrm{d}^{-1}$ (HRT15 日) となっており, $\mathrm{COD}_{\mathrm{Cr}}$ 容積負荷に比例して増大した $\left(\mathrm{R}^{2}=0.99\right)$ 。擋拌 直後の状態から第 1 チャンバーにバイオガスが $4.3 \mathrm{~L}$ 蓄 積することで 1 回の擋拌が生じる。従って, 擋拌頻度は 第 1 チャンバーから発生するバイオガス生成速度に依存 している。リアクター運転結果から明らかなように，バ イオガス生成速度は $\mathrm{COD}_{\mathrm{Cr}}$ 容積負荷上昇に比例して増 大しているため, 擋拌頻度も増大したわけである。上で 述べたように，第 1 チャンバーにおけるガス生成速度の リアクター全体におけるそれに占める割合はすべての HRT で約 23 ～34\%であった。また，第 1 チャンバーか ら発生するバイオガスのメタン濃度はすべての HRT で 48 〜 $58 \%$ の同様の範囲で推移していた。つまり,す心゙ ての HRT 条件において発生するメタンガスの多くは第
1 チャンバーに由来しているといえる。以上のことから， 第 1 チャンバーで活発なメタン生成が行われることが擋 拌頻度増加の鍵であると考えられる。リアクター内部の 污泥性状分析から判明したように, 第 1 チャンバーにお いて深刻なVFA 蓄積や $\mathrm{pH}$ 低下が起こらずに安定した 運転ができたことが, $\mathrm{COD}_{\mathrm{Cr}}$ 容積負荷増大に伴う擋拌頻 度増加につながったといえる。こうしたリアクターの反 応特性を理解した上で, 擋拌頻度の増大と安定を確保す るための装置デザインの最適化を今後の研究課題とした い。

\section{5 無動力擋拌リアクターの運転性能評価}

\subsection{1 滞留時間による影響}

Table 2 には各 HRT における定常状態の運転性能の平 均值をまとめた。表の上段に示す流出液の $\mathrm{pH}$, アルカ リ度, VFAの平均值およびその標準偏差から判断して, 上でも議論したようにすべての HRT 条件においてメ夕 ン発酵にとって安全な水準での運転が安定的に行われた といえる。表中段に示す $\mathrm{COD}_{\mathrm{Cr}}, \mathrm{TS}, \mathrm{VS}, \mathrm{SS}, \mathrm{VSS}$ 各 減量化率はすべて HRT 短縮に伴い減少の傾向があるが, 最短の HRT 15 日においても COD $_{\mathrm{Cr}}$ 減量化率は約 $80 \%$, VS 減量化率も約 $82 \%$ を保持しているので, HRT 30 日 のそれらと比較して著しい性能悪化ではない。表下段に 示すバイオガス生成特性からは，投入基質量あたりの バイオガス生成倍率およびガス組成に関して, HRT 短 縮に伴う顕著な変化は認められなかった。以上のことか ら判断して, 生ごみでの $\mathrm{COD}_{\mathrm{Cr}}$ 容積負荷約 $10 \mathrm{~kg} \cdot \mathrm{m}^{-3} \cdot \mathrm{d}^{-1}$ までの運転は本無動力擋拌リアクターの許容範囲内であ ると評価できる。

\subsubsection{CSTR との運転性能比較}

本研究では, 無動力擋拌リアクターが擋拌動力ありの CSTR と同等以上のメタン発酵性能を有することを目標 の一つとした。本研究と同じ組成の模擬生ごみを用いた メタン発酵の研究が, 李らによってこれまで報告されて きた ${ }^{8,16,17)}$ 。Table 3 は, 本研究と同じ組成の模擬生ごみ を基質とする，擋拌動力ありの CSTR による中温メタン

Table 2 Average performances of the reactor with different HRTs at steady state.

\begin{tabular}{cccc}
\hline $\mathrm{HRT}(\mathrm{d})$ & 30 & 20 & 15 \\
\hline $\mathrm{pH}$ & $7.78 \pm 0.09$ & $7.94 \pm 0.08$ & $7.83 \pm 0.04$ \\
Alkalinity pH $4.8\left(\mathrm{~g} \cdot \mathrm{L}^{-1}\right.$ as $\left.\mathrm{CaCO}_{3}\right)$ & $9.64 \pm 0.56$ & $7.47 \pm 0.53$ & $7.21 \pm 0.17$ \\
\hline $\mathrm{T}-\mathrm{COD} \mathrm{Cr}\left(\mathrm{g} \cdot \mathrm{L}^{-1}\right)$ & $20.9 \pm 0.4$ & $27.6 \pm 1.6$ & $30.0 \pm 2.5$ \\
$\mathrm{VFA}\left(\mathrm{mg} \cdot \mathrm{L}^{-1}\right.$ as acetate $)$ & $17 \pm 39$ & $26 \pm 17$ & $<1$ \\
$\mathrm{NH}_{4}{ }^{-} \mathrm{N}\left(\mathrm{mg} \cdot \mathrm{L}^{-1}\right)$ & $2,060 \pm 50$ & $1,580 \pm 60$ & $1,780 \pm 120$ \\
\hline $\mathrm{COD} \mathrm{Cr}_{\text {reduction }(\%)}$ & $85.5 \pm 0.6$ & $80.7 \pm 0.9$ & $79.4 \pm 2.3$ \\
$\mathrm{TS} \mathrm{reduction}(\%)$ & $81.0 \pm 0.6$ & $79.9 \pm 1.1$ & $77.3 \pm 2.0$ \\
$\mathrm{VS} \mathrm{reduction}(\%)$ & $86.4 \pm 0.3$ & $84.3 \pm 0.8$ & $81.9 \pm 1.8$ \\
\hline Biogas production rate $\left(\mathrm{L} \cdot \mathrm{L}^{-1} \cdot \mathrm{d}^{-1}\right)$ & $2.23 \pm 0.10$ & $3.46 \pm 0.14$ & $4.71 \pm 0.19$ \\
Biogas production ratio $\left(\mathrm{L} \cdot \mathrm{L}^{-1}-\mathrm{substrate}\right)$ & $73.5 \pm 3.3$ & $73.4 \pm 3.4$ & $74.9 \pm 3.0$ \\
$\mathrm{CH}_{4}(\%)$ & $55.7 \pm 0.8$ & $57.6 \pm 1.7$ & $55.7 \pm 1.4$ \\
$\mathrm{CO}_{2}(\%)$ & $41.6 \pm 0.9$ & $41.1 \pm 1.8$ & $43.0 \pm 1.3$ \\
$\mathrm{~N}_{2}(\%)$ & $2.9 \pm 0.6$ & $1.9 \pm 0.2$ & $1.6 \pm 0.4$ \\
\hline
\end{tabular}


Table 3 Comparison between average performances of the self-agitated reactor and CSTR.

\begin{tabular}{ccccc}
\hline & \multicolumn{2}{c}{ This study } & \multicolumn{2}{c}{ CSTR $^{8)}$} \\
\hline Substrate & \multicolumn{2}{c}{ Stimulated food waste $\left(\mathrm{TS} 100 \mathrm{~g} \cdot \mathrm{L}^{-1}\right)$} \\
\hline HRT $(\mathrm{d})$ & 30 & 15 & 30 & 15 \\
\hline $\mathrm{COD}_{\mathrm{Cr}}$ loading rate $\left(\mathrm{kg} \cdot \mathrm{m}^{-3} \cdot \mathrm{d}^{-1}\right)$ & $4.82 \pm 0.13$ & $9.74 \pm 0.39$ & 5.07 & 10.1 \\
\hline $\mathrm{VFA}\left(\mathrm{mg} \cdot \mathrm{L}^{-1}\right.$ as acetate) & $17 \pm 39$ & $<1$ & Approx. 100 & Approx. 100 \\
$\mathrm{COD}$ Cr reduction $(\%)$ & $85.5 \pm 0.6$ & $79.4 \pm 2.3$ & 83 & 79 \\
TS reduction $(\%)$ & $81.0 \pm 0.6$ & $77.3 \pm 2.0$ & 78 & 73 \\
VS reduction $(\%)$ & $86.4 \pm 0.3$ & $81.9 \pm 1.8$ & 83 & 78 \\
Biogas production yield $\left(\mathrm{m}^{3} \cdot \mathrm{kg}^{-1}-\mathrm{TS}\right)$ & $0.82 \pm 0.06$ & $0.73 \pm 0.06$ & 0.70 & 0.73 \\
\hline
\end{tabular}

発酵の定常状態期間の運転性能と本研究のそれとの比較 を示している。この CSTR では $\mathrm{COD}_{\mathrm{Cr}}$ 容積負荷も本研 究とほとんど同じ条件で実験を行っている。両 HRT 条 件おいて, 流出液 VFA 濃度はCSTRよりも無動力擋拌 リアクターの方が明らかに低水準であった。このことに は，上で述べたように内部で有機物分解の役割分担が ある本リアクターの反応特性が寄与していると考えら れる。全体で均一に反応が進行するCSTR と比較して, VFA 分解に特化した領域を有する本リアクターでは微 量のVFA を残留させにくいと推察される。また, 同じ く両 HRT で無動力擋拌リアクターの $\mathrm{COD}_{\mathrm{Cr}}$, TS, VS 減量化率のそれぞれは, CSTRのそれらをわずかに上回 る数值を示した。無動力撹拌リアクターの投入 TS あた りのバイオガス生成収率は, HRT 30 日において CSTR のそれの 1.1 倍程度, HRT 15 日において CSTRのそれ と同程度であった。以上述べた観点からは, 本研究の無 動力擋拌リアクターは, 擋拌動力ありの CSTR と同等以 上の運転性能を示したということができる。

\section{4. まとめ}

簡易な構造で無動力の擋拌機構を実現するためにデザ インした新規メタン発酵リアクターを用いて, 模擬生ご みを基質として連続運転を行ったところ， $\mathrm{COD}_{\mathrm{Cr}}$ 容積負 荷約 $5 \mathrm{~kg} \cdot \mathrm{m}^{-3} \cdot \mathrm{d}^{-1}$ から $10 \mathrm{~kg} \cdot \mathrm{m}^{-3} \cdot \mathrm{d}^{-1}$ の範囲で安全かつ安 定した運転が可能であった。 $\mathrm{COD}_{\mathrm{Cr}}$ 収支の結果から判断 して, 有機物のリアクター内蓄積は回避できた。本リア クターは, $\mathrm{COD}_{\mathrm{Cr}}$ 減量化率, バイオガス生成収率, 流出 液 VFA 濃度の観点から, 擋拌動力ありの CSTR 用い た同負荷の運転と比較して同等以上の運転性能が実現で きた。

（原稿受付 2010 年 9 月 15 日) （原稿受理 2010 年 10 月 27 日)

\section{参 考 文 献}

1 ) Huttunen, S. and Lampinen, A. (2005) Bioenergy technology evaluation and potential in Costa Rica, University of Jyvaskyla printing house, Jyvaskyla, Finland.

2 ） Chew, C. S. (2007)「中国の再生可能エネルギー中長期発展計画 -バイオマス資源の開発 -」, http://eneken.ieej.or.jp/data/pdf/1464. pdf (2010年9月 1 日時点).

3 ) Lansing, S., Botero, R. B. and Martin, J. F. (2008) Waste treatment and biogas quality in small-scale agricultural digesters, Bioresour. Technol, 99 (13), 5881-5890.

4 ) Lansing, S., Víquez, J., Martínez, H., Botero, R. and Martin, J. (2008) Quantifying electricity generation and waste transformations in a lowcost, plug-flow anaerobic digestion system, Ecol. Eng, 34, 332-348.

5 ) Lansing, S., Martin, J. F., Botero, R. B., da Silva, T. N. and da Silva, E. D. (2010) Methane production in low-cost, unheated, plug-flow digesters treating swine manure and used cooking grease, Bioresour. Technol, 101 (12) , 4362-4370.

6 ) Karim, K., Hoffmann, R., Klasson, T. and Al-Dahhan, M. H. (2005) Anaerobic digestion of animal waste: waste strength versus impact of mixing, Bioresour. Technol, 96 (16), 1771-1781.

7 ) 徐開欽, 蛯江美孝, 神保有亮 (2010) 中国農村地域における液 状廃棄物処理の現状と課題 - 北京市延慶県永寧鎮新華営村の事 例紹介-, 用水と廃水, 52 (2), 12-18.

8 ) 李玉友, 佐々木宏, 鳥居久倫, 奥野芳男, 関廣二, 上垣内郁夫 （1999）生ごみの高濃度消化における中温と高温処理の比較, 環境 工学研究論文集, 36, 413-421.

9 ）日本下水道協会（1997）下水試験方法上巻, 812pp., 日本下水 道協会, 東京.

10) APHA (1995) Standard methods for the examination of water and wastewater, 19thed, American public health association, Washington, D. C.

11）小林拓朗, 李玉友, 久保田健吾, 原田秀樹, 前田武巳, 河合和保, 吉田尊彦 (2009) 硫黄酸化細菌を利用したメタン発酔槽の微好気 環境下に打けるバイオガス脱硫, 土木学会論文集 G, 65 (2), 104113.

12） Speece, R. E.（1999）産業廃水処理のための嫌気性バイオテク ノロジー, 462pp., 技報道出版, 東京.

13) Nachaiyasit, S. and Stuckey, D. C. (1995) Microbial response to environmental changes in an anaerobic baffled reactor (ABR), Anton. Leuwen, 67, 111-123.

14) Wang, J., Huang, Y. and Zhao, X. (2004) Performance and characteristics of an anaerobic baffled reactor, Bioresour. Technol, $\mathbf{9 3}$ (2), 205-208

15) Ferguson, J. F., Eis, B. J. and Benjamin, M. M. (1984) Neutralization in anaerobic treatment of an acidic waste, Water Res, $\mathbf{1 8}$, 573-580.

16）佐々木宏, 李玉友, 関廣二, 上坦内郁夫 (1999) 生ごみの高温 · 高濃度メタン発酵に及ぼす滞留時間と負荷の影響, 水環境学会誌, 22 (12), 983-989.

17) Li, Y. Y., Noike, T., Mizuno, O. and Funaishi, K. (2006) A new twophase process for waterless methane fermentation treating the organic fraction of MSW, J. Environ. Eng. Management, 16 (5), 297-302. 